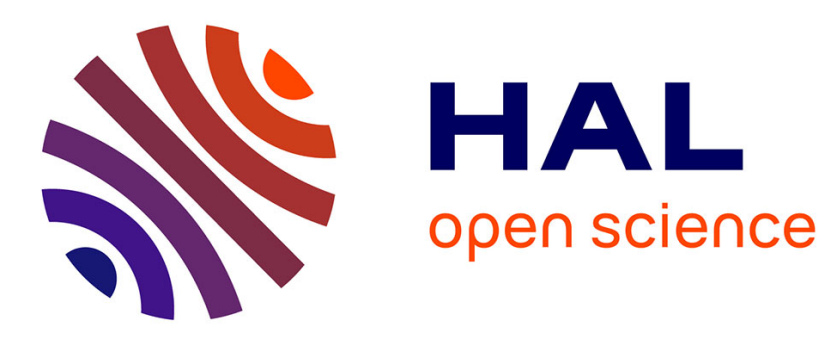

\title{
Humus profiles under main vegetation types in a rock savanna (Nouragues inselberg, French Guiana)
}

Charlotte Kounda-Kiki, Anne Vaçulik, Jean-François Ponge, Corinne Sarthou

\section{To cite this version:}

Charlotte Kounda-Kiki, Anne Vaçulik, Jean-François Ponge, Corinne Sarthou. Humus profiles under main vegetation types in a rock savanna (Nouragues inselberg, French Guiana). Geoderma, 2006, 136 (3-4), pp.819-829. 10.1016/j.geoderma.2006.06.007 . hal-00508381

\section{HAL Id: hal-00508381 https://hal.science/hal-00508381}

Submitted on 3 Aug 2010

HAL is a multi-disciplinary open access archive for the deposit and dissemination of scientific research documents, whether they are published or not. The documents may come from teaching and research institutions in France or abroad, or from public or private research centers.
L'archive ouverte pluridisciplinaire HAL, est destinée au dépôt et à la diffusion de documents scientifiques de niveau recherche, publiés ou non, émanant des établissements d'enseignement et de recherche français ou étrangers, des laboratoires publics ou privés. 
1 Humus profiles under main vegetation types in a rock savanna (Nouragues inselberg, 2 French Guiana)

4 Charlotte Kounda-Kiki, Anne Vaçulik, Jean-François Ponge* and Corinne Sarthou

Muséum National d'Histoire Naturelle, CNRS UMR 5176, 4 Avenue du Petit Château, 91800 Brunoy, France

Abstract

The aim of our study was to describe succession related changes in humus profiles on moderate slopes of a tropical inselberg (Nouragues, French Guiana). Nine humus profiles were collected in a stratified manner under two main communities on well-drained sites: carpets of Pitcairnia geyskesii (Bromeliaceae) and shrub thickets of Clusia minor (Clusiaceae), the latter including two stages of its dynamic development. The 53 sampled layers were analysed by an optical method, the volume ratio of 109 classes of litter/humus components being quantified by a count point method. Correspondence analysis (CA) revealed marked differences among humus forms. Pitcairnia carpets were characterized by the dominance of cyanobacteria which formed crusts with low faunal activity, except when they were colonized by enchytraeid worms. With advancing succession, we observed that leaf

21 litter did not accumulate but rather was incorporated into organo-mineral excrements of 22 macro-invertebrates under $C$. minor. The late developmental stage of Clusia thickets, characterised by the establishment of Myrcia saxatilis (Myrtaceae), showed a thick layer of undecayed litter and near absence of organo-mineral aggregates. The humus form varied from

\footnotetext{
*Fax: +33-1-60479213. E-mail address: jean-francois.ponge@wanadoo.fr
} 
1 mor in cyano-bacterial crusts to tropical moder (with a few mull features) in Clusia thickets,

2 but comparisons among humus profiles revealed more complex successional processes than

3 expected on the basis of the composition of plant and soil animal communities.

Keywords: Humus form; Micromorphology; Tropical soils; Rock savanna

\section{Introduction}

Despite the widely reported lack of organic matter and nutrients in tropical soils, due to rapid mineralization of leaf and root litter and intense leaching (Lavelle, 1984; Lavelle et al., 1993), huge accumulations of organic matter can be observed on rocky substrates and nutrient-depleted sandy soils (Lips and Duivenvoorden, 1996; Loranger et al., 2003).

In French Guiana, inselbergs in the form of granite outcrops rise abruptly from the surrounding rain forest (Bremer and Sander, 2000). They constitute isolated islands of a special type of vegetation restricted to this peculiar substrate. Unique plant communities occur on these inselbergs, including predominantly evergreen and sclerophyllous shrubs, belonging to Clusiaceae, Myrtaceae and Bombacaceae (Sarthou and Villiers, 1998).

On the basis of earlier studies on vegetation types and soil communities (Sarthou and

21 Grimaldi, 1992; Sarthou and Villiers, 1998; Vaçulik et al., 2004; Kounda-Kiki et al., 2004),

22 we studied the variation in the composition of humus horizons along a succession sequence 23 on the Nouragues inselberg. Our aim was to describe in detail the composition of these 24 superficial organic soils (Hambler, 1964; Sarthou and Grimaldi, 1992; Bremer and Sander, 25 2000) and to understand what happens during the development of cryptogamic then 
1 phanerogamic vegetation. Pitcairnia geyskesii L.B. Smith (Bromeliaceae, herb) and Clusia

2 minor L. (Clusiaceae, shrub) communities represent two seral stages of a low vegetation

3 called rock savanna, which is established on moderate slopes (Sarthou, 1992). Within the

4 Clusia community, two sub-stages can be distinguished, the one represented by C. minor 5 only, the other by the late addition of Myrcia saxatilis (Amshoff) McVaugh (Myrtaceae) and 6 several other woody species.

7

The successional development of humus profiles was analysed by studying different members of a successional sere. Results were statistically analysed by Correspondence Analysis (Greenacre, 1984).

\section{Materials and methods}

\subsection{Study site}

The field work was carried out at the Nouragues inselberg in French Guiana (411 m above sea level), which protrudes from a plateau in the Nouragues natural reservation $\left(4^{\circ} 5^{\prime} \mathrm{N}\right.$ and $\left.52^{\circ} 42^{\prime} \mathrm{W}\right)$. The inselberg is a tabular outcrop of Caribbean granite, of pinkish monzonitictype, containing on average $27 \%$ potassium-feldspar (orthoclase) and $37 \%$ plagioclase, along with $33 \%$ quartz as coarse-grained crystals and $2 \%$ accessory minerals (pyroxene, corundum, apatite) (Grimaldi and Riéra, 2001). Whole-rock chemical analysis (Sarthou, 1992) shows that the granite is highly siliceous $\left(76.4 \% \mathrm{SiO}_{2}\right)$ and rich in alkalis $\left(4.6 \% \mathrm{~K}_{2} \mathrm{O}, 4.2 \% \mathrm{Na}_{2} \mathrm{O}\right)$. The climate is tropical humid, with a dry season from July to November and a wet season from December to June that is interrupted by a very short dry period in March. Mean annual precipitation is $3000 \mathrm{~mm}$. The daily temperature varies from 18 to $55^{\circ} \mathrm{C}$ and the daily air 
1 humidity from 20 to $100 \%$ (Sarthou, 1992). The temperature of the bare rock surface may

2 reach $75^{\circ} \mathrm{C}$ in the dry season. Most of the surface of the granitic outcrop is covered by 3 cyanobacteria (Sarthou et al., 1995). The bromeliad P. geyskesii is the most typical plant of 4 the inselberg. This epilithic species (30-50cm tall) always forms dense carpets, covering low 5 to medium slopes as well as gullies and shallow depressions (Sarthou and Villiers, 1998). The 6 C. minor (Clusiaceae) community is also widespread (Sarthou, 2001; Sarthou et al., 2003). It 7 represents the shrub vegetation unit of the rock savanna, forming dense thickets of 2-8 $\mathrm{m}$ tall shrubs. This woody vegetation occurs in depressions and slopes that have sandy and organic soils, respectively. On moderate slopes a succession takes place, from an early stage characterized by cyanobacterial crusts and herbaceous vegetation (Pitcairnia), to mid and late stages which can be identified in shrub (Clusia) thickets (Sarthou, 2001). C. minor establishes from seeds within carpets of $P$. geyskesii and subsequently spreads vegetatively, in the end developing into pure $C$. minor thickets with an outer circle of herbaceous vegetation. Various woody species, among which M. saxatilis (Myrtaceae) is the most important one, progressively enrich $C$. minor thickets, without replacing it, forming the late stage of development of shrub vegetation. Intense runoff and violent storms, combined with internal destruction of shrub vegetation by xylophagous fungi and termites, cause a periodical return to pioneer stages of the sequence (personal observations), but we are unable to indicate the time required for reaching each stage of the vegetation succession.

The present study was undergone on moderate slopes (30-35\%), where soils are poorly differentiated. They are made of humified organic matter, which accumulate in cyanobacterial crusts and in the dense root mats of vegetation patches (Sarthou and Grimaldi, 1992). These organic soils are acidic $\left(\mathrm{pH}_{\mathrm{KCl}} \leq 4\right)$ and poor in nitrogen $(\mathrm{C} / \mathrm{N}=20-30)$. They are poorly 
1 anchored to the granite and are subject to intense erosion. During showers, water can be seen

2 to flow freely between the granite and the lower side of the organic mass.

\subsection{Sampling of humus profiles}

In each vegetation type three sites were sampled. Sampling took place in April 2002.

The low level of replication of our sampling procedure was due to remoteness of the sites and lack of commodities for carrying samples to the French (metropolitan) laboratory. Three humus profiles were sampled in the Pitcairnia community (cyanobacterial crusts) and three in each of two dynamic stages of the Clusia community (Clusia and Clusia-Myrcia). The nine vegetation patches were selected in the lower part of the inselberg, in an area with moderate slope (30-35\%) and South-facing aspect, locally called 'Les Terrasses'. Selection of sampling points was done after a thorough examination of all vegetation patches which were present at the study site (ca. 50), all of them being associated to a step of the plant succession according to Sarthou (2001), on the base of their architecture and floristic composition. We arbitrarily selected three patches in each of the three successional stages. At the centre of a vegetation clump, a block of surface soil $25 \mathrm{~cm}^{2}$ in area and $10 \mathrm{~cm}$ depth (except when the soil was shallower) was arbitrarily selected, then cut with a sharp knife, with as little disturbance as possible, and litter and soil underneath were carefully sampled. When a stone or a large root was encountered in the top $10 \mathrm{~cm}$, we discarded the sample then we arbitrarily selected another location. It was decided to sample only the top $10 \mathrm{~cm}$ because most pronounced stratification of the topsoil was seen to occur within this depth. In Clusia-Myrcia communities, sampling was under the canopy of $M$. saxatilis. However, we could not exclude the possible admixture of $C$. minor dead leaves and root systems from shrubs growing in the immediate vicinity. In the field each humus block was separated into individual layers that 
1 macroscopically could be identified on their structure, composition or other relevant

2 properties (Peltier et al., 2001). The various layers were transferred into polypropylene jars

3 filled with $95 \%$ ethanol before transport to the laboratory. Care was taken that the jars were

4 completely filled with the sampled material in order to avoid changes in structure resulting

5 from shaking during transport to the laboratory. Thicknesses of individual layers ranged from

$6 \quad 0.5$ to $3 \mathrm{~cm}$. The layers were classified into OL (entire leaves), OF (fragmented leaves) and

$7 \mathrm{OH}$ (humified material) horizons, according to the classification of Brêthes et al., (1995), other soil horizons being absent. When several layers were sampled in the same horizon (on the basis of visible differences) sub-samples were numbered successively according to their order from the top to the bottom of a given horizon, for example OL1, OL2, OF1, OF2, OH1, $11 \mathrm{OH} 2 \ldots$

All 53 layers were microscopically studied using the 'small volume' micromorphological method developed by Bernier and Ponge (1994), to which reference is made for details. Results from grid point counting (429 points) were expressed as the percentage of a given class of litter/humus component. 109 classes of litter/humus components were identified (see Appendix).

The various kinds of plant debris were identified visually by comparison with a collection of main plant species growing in the vicinity of the sampled humus profiles. Litter

21 leaves were classified according to plant species and decomposition stages on the basis of morphological features. Dead and living roots were separated by colour and turgescence state, helped when possible by the observation of root sections. Animal faeces were classified by the size, the shape, the degree of mixing of mineral matter with organic matter and colour according to animal groups when possible (Bal, 1982; Ponge, 1991; Topoliantz et al., 2000). 
1 When necessary, the identification of litter/humus components was checked at higher

2 magnification. For that purpose, a small piece of a given litter/humus component was 3 mounted in a drop of chloral-lactophenol for examination in a phase contrast microscope at 4400 X magnification.

After the quantification of litter/humus components was completed, each sample was thoroughly inspected under the dissecting microscope, in order to establish all enchytraeids that were present in the corresponding layer. This allowed us to add these terrestrial annelids, which were poorly extracted by Berlese funnels (Kounda-Kiki et al., 2004) as an additional item to the list of litter/humus components.

For bulk comparisons between the three main vegetation types the 109 classes of humus components were pooled into 10 gross categories, taking into account the decomposition stage of plant litter, its transformation into animal faeces and the degree of incorporation of organic matter to mineral matter, without resorting to animal and plant 16 species (Table 1 and Appendix).

17

The material studied has been partly described in a previous paper dealing only with cyanobacterial crusts (Vaçulik et al., 2004). For the present study the corresponding microlayers have again been analysed by the same person (C. Kounda-Kiki).

\subsection{Data analysis}

Percentages of occurrence of classes of litter/humus components in the 53 microlayers investigated were subjected to a correspondence analysis or CA (Greenacre, 1984). The 
1 different classes of litter/humus components were the active (main) variables, coded by their

2 percentage of occurrence by volume. Passive variables ( $\mathrm{OL}, \mathrm{OF}, \mathrm{OH}$ horizons, vegetation 3 types, depth levels) were added in order to facilitate the interpretation of factorial axes

4 (Sadaka and Ponge, 2003).

All variables were transformed into $X=(x-m) / s+20$, where $x$ is the original value, $m$ is the mean of a given variable, and $s$ is its standard deviation (Sadaka and Ponge, 2003). The addition to each standardized variable of a constant factor of 20 allows all values to be positive, CA dealing only with positive numbers. Factorial coordinates of weighted variables (constant mean and variance) can be interpreted directly in terms of their contribution to the

11 factorial axes (Greenacre, 1984).

The volume percent of a given class (or gross category) of litter/humus component can be averaged over the whole profile, taking into account the different micro-layers, each individual value being weighted by the thickness of the corresponding micro-layer. This allowed to calculate the mean percent volume of the different classes of litter/humus components and of the gross categories in each humus profile (Table 1 and Appendix).

\section{Results}

The results given below should be taken only as indicative of the variety of humus profiles found under rock savanna vegetation, due to the low degree of replication used in our study. 


\subsection{Micromorphological analyses}

2

Most material present in the studied profiles was leaf and root material in varying stages of decomposition (see Appendix). Table 1 shows the distribution of the 10 gross categories of litter/humus components under the three vegetation types studied. Notice that these gross categories were not mutually exclusive, thus their total was above $100 \%$. For instance, all components comprising fungal mycelia were included in the gross category 'Fungal mycelium', while some of them were also included in other gross categories.

Cyanobacteria were only found in Pitcairnia humus profiles (cyanobacterial crusts bordering bromeliad carpets). There were but few organo-mineral faeces in Clusia-Myrcia and none in Pitcairnia profiles (Table 1). Fungal mycelia were almost absent throughout Pitcairnia profiles. The number of enchytraeids per $\mathrm{cm}$ of profile was at its highest in one sample of the Pitcairnia stage (see Appendix). Charcoal was totally absent from our material.

The 10 gross categories were used to build simplified profile diagrams, on the base of data averaged for each vegetation type. Cyanobacteria were present only in the early stage of vegetation succession, under Pitcairnia (Fig. 1a). Figure 1b shows that leaf material decreased with depth, with a corresponding increase of roots (Fig. 1c). Decayed plant material increased in volume under Pitcairnia down to $3 \mathrm{~cm}$, indicating that it was overgown by the cyanobacterial crust, then decreased slowly (Fig. 1d). Under the other two vegetation types decayed plant material decreased with depth. This was associated with a higher activity of fungi under Clusia and Clusia-Myrcia (Fig. 1e). Fungi were visible under Pitcairnia in the topmost $\mathrm{cm}$, but disappeared beneath. An increase then a decrease in humified organic matter was observed below $5 \mathrm{~cm}$ under Clusia and Clusia-Myrcia (Fig. 1f). Examination of the 
1 faecal material showed that it began to accumulate in the first $\mathrm{cm}$ (Figs. 1g, 1h). Holorganic

2 faeces from millipedes, mites, enchytraeids, woodlice, earthworms, snails, insect larvae

3 (recognizable from their size and shape) and undetermined fauna increased with depth (Fig.

4 1g). Organo-mineral dominant animal faeces (millipedes and earthworms) were present in the

5 surface layer under Clusia vegetation, then disappeared from 2 to $4 \mathrm{~cm}$, then increased

6 abruptly below $4 \mathrm{~cm}$. There were but few organo-mineral faeces present under Clusia-Myrcia

7 and none under Pitcairnia (Fig. 1h). Despite their large content of organic matter, shown by

8 their black colour, organo-mineral faeces contain numerous mineral particles, visible under

9 the microscope. The percent volume of mineral particles increased from the top to the bottom

10 of humus profiles under Clusia and Clusia-Myrcia, under Pitcairnia mineral particles were

11 much more abundant: they increased down to $2 \mathrm{~cm}$ then decreased to $5 \mathrm{~cm}$ and increased

12 abruptly below $6 \mathrm{~cm}$, at the contact with the granite (Fig. 1i).

3.2. Synthesis by correspondence analysis (CA)

15

16

The projection of active (main) and passive (additional) variables in the plane of the first two factorial axes (8.9 and $7.7 \%$ of the total variance, respectively) showed a marked heterogeneity among horizons (OL, OF, OH) and among humus profiles (Figs. 2, 3). Given the number of rows (53) and columns (109) of our data matrix, the part of the total variance extracted by each of the first two factorial axes was significantly different from random (Lebart et al., 1979), and the distribution of active and passive variables in the plane of the first two axes showed a meaningful structure. Mineral particles and cyanobacteria were projected on the positive side of Axis 1, which separated Pitcairnia from other vegetation. Axis 2 was correlated with depth (surface with positive values, depth with negative values). Leaf material and decayed plant material were projected on the positive side of Axis 2, root 
1 material being projected on the negative side of Axis 2. Excrements (holorganic and organo-

2 mineral faeces) were projected on the negative side of Axis 2.

3

Figure 3 expressed the changes occurring vertically along humus profiles (mean trajectories for each vegetation type) and the distribution of horizons and vegetation types. Pitcairnia was characterized by positive values of Axis 1 and was well separated from the other two vegetation types. This means that humus profiles under Pitcairnia (cyanobacterial crust) had a distinct composition. Along Axis 1, the sample Pit 3 was clearly separated from Pit 1 and Pit 2, being farther from the origin: this profile exhibited a better differentiated composition than the tow other profiles sampled under Pitcairnia. Clusia and Clusia-Myrcia were characterized by negative values of Axis 1 . Axis 2 displayed the vertical distribution of $\mathrm{OL}, \mathrm{OF}$ and $\mathrm{OH}$ horizons in the woody vegetation types. The OL horizon was restricted to the surface of the profiles (positive values of Axis 2), the OF horizon was placed in an intermediate position between $\mathrm{OL}$ and $\mathrm{OH}$ horizons (not far from the origin) and the $\mathrm{OH}$ horizon underneath (negative values of Axis 2). Despite strong differences between the humus profiles sampled under a given vegetation type, on average OL and OF horizons characterized Clusia-Myrcia more than Clusia.

The projection of depth level indicators in the plane of the first two axes of CA clarified vertical changes in the composition of humus profiles and revealed differences in the rate of horizon differentiation between Clusia and Clusia-Myrcia. Linking successive depth levels by straight lines displayed depth trajectories and revealed mean trends, helping us to show changes in humus composition along topsoil profiles under the different vegetation types (Fig. 3). The composition of the surface horizon was quite similar under Clusia and Clusia-Myrcia, being typical of an OL horizon. However, at the bottom of humus profiles (10 
$\mathrm{cm}$ ), the composition of horizons was typical of an $\mathrm{OH}$ horizon under Clusia, being mainly made of excrement and root material (Fig. 2), while it was still that of an OF horizon under Clusia-Myrcia.

\section{Discussion}

\subsection{Pitcairnia stage}

The poor decay of the plant material observed under the bromeliad Pitcairnia, i.e., litter from neighbouring vegetation included into cyanobacterial crusts, could be explained by a very low amount of fungal and macro-invertebrate activity, compared to further stages of succession. The composition of the faecal material in Pitcairnia humus profiles revealed the absence of soil macro-fauna under the cyanobacterial crust, which was confirmed by faunal data (Kounda-Kiki et al., 2004; Vaçulik et al., 2004). Meso-fauna was also hardly active, except in Pit 3 which contained a large volume of enchytraeid faeces (Appendix). Within our limited sampling, Pit 3 depicted more soil development than the other two samples which were done in cyanobacterial crusts. In the absence of earthworms enchytraeids play a leading role in soil development (Didden, 1990). These animals were substituted by earthworms and other macro-invertebrates under the two other vegetation types, as shown by faecal deposition (the present study) and faunal extraction (Kounda-Kiki et al., 2004).

\subsection{Clusia and Clusia-Myrcia stages}

Decayed plant material decreased over a short distance in the humus profiles under Clusia and Clusia-Myrcia stages with a greater activity of fungi and macro-invertebrates 
1 (Kounda-Kiki et al., 2004), and litter was transformed into humus over a short distance under

2 Clusia. The presence of fungi and the intense earthworm activity observed under Clusia and

3 Clusia-Myrcia should be noted. They possibly indicate an increase in organic matter

4 decomposition accompanying the development of woody vegetation, despite an increase in

5 primary production when prostrated bromeliad carpets are locally replaced by dense shrub

6 thickets.

7

Results on soil arthropod communities showed that species diversity and abundance were highest at the Clusia-Myrcia stage (Kounda-Kiki et al., 2004). We cannot rule out a possible higher foliage and root litter input at the Clusia-Myrcia stage, which could be in excess of soil community requirements (Garay and Hafidi, 1990). The accumulation of surface organic matter (undecayed litter) could also be due to terpene production by Myrtaceae (Boland and Brophy, 1993). To the light of our results (Kounda-Kiki et al., 2004; the present study) the recalcitrant nature of Clusia-Myrcia litter seems to offer better conditions for macro-fauna than Clusia-only litter. The situation can be described as a balance between positive (shelter) and negative (recalcitrance) effects, that results in an overall positive effect for the animal community. A similar trade-off has been hypothesized in semiarid ecosystems (Peltier et al., 2001).

\subsection{The sequence of soil development on the Nouragues inselberg}

On the basis of their horizons the humus forms we described under rock savanna belong to a group of tropical humus forms on nutrient-depleted or rocky substrates, which are characterized by the accumulation of faunal excrements within a dense root mat, without or with a poor incorporation of organic matter to the mineral soil (Lips and Duivenvoorden, 
1 1996; Loranger et al., 2003). They share common features with moder which has been

2 described in temperate regions (Green et al., 1993). However, two samples taken under

3 Pitcairnia (Pit 1 and Pit 2) did not display such accumulation of faeces. They exhibited a

4 single horizon, made of accumulated cyanobacteria, quite similar to surface vegetation. These

5 features are typical of mor, if we consider cyanobacterial remains as plant remains. On the

6 other hand, the presence of earthworm and millipede organo-mineral faeces under Clusia

7 indicate the (limited) formation of hemorganic assemblages typical of temperate mull 8 (Brêthes et al., 1995).

9

Recent observations on the Nouragues inselberg point on the importance of erosive processes in the establishment of Myrcia saxatilis and other Myrtaceae within thickets of Clusia minor. The destruction of stems and branches of $C$. minor by wood-feeding termites and wood fungi creates gaps which allow the establishment by seed of more woody species. Partial or near total erosion of the organic soil which forms during the development of $C$. minor occurs when the soil remains unprotected (Sarthou et al., in prep.). This erosive process allows the rock savanna to rejuvenate periodically, at least on slopes. Awaiting further development of our study, the successional sequence here described should be considered as a combination of a primary sequence, i.e. the passage from bare rock to Pitcairnia then to Clusia profiles, and a secondary sequence from Clusia to Clusia-Myrcia, following partial erosion of the organic soil.

\section{Conclusions}

Although limited by the low degree of replication and lack of chemical data, our study described for the first time the composition of organic soils of tropical inselbergs. The 
1 biological origin of most components can be traced, on the basis of recognizable features of

2 rootq and faeces and previous analyses of soil animal communities (Kounda-Kiki et al.,

3 2004). Strong variation occurs between vegetation types of the rock savanna, the successional

4 development of vegetation being accompanied by the appearance of soil structure: first a fine-

5 grained structure created by enchytraeid activity in the absence of macrofauna under

6 cyanobacterial crusts, then a coarse-grain structure created by earthworms and millipede

7 activity under woody leaf litter. The establishment of Myrtaceae within thickets of C. minor

8 (the dominant scrub vegetation of the rock savanna) seems to indicate a decrease in the

9 process of bioturbation, possibly due to erosive processes followed by the input of a more

10 recalcitrant litter.

\section{Acknowledgements} Field Station.

\section{References}

Bal, L., 1982. Zoological Ripening of Soils. Pudoc, Wageningen.

Bernier, N. and Ponge, J. F., 1994. Humus form dynamics during the sylvogenetic cycle in a mountain spruce forest. Soil Biol. Biochem., 26: 183-220. 
1 Boland, D. J., and Brophy, J. J., 1993. Essential oils of the eucalypts and related genera. ACS Symp. Ser., 525: 72-87.

3

4 Bremer, H., and Sander, H., 2000. Inselbergs: geomorphology and geoecology. In: S. 5 Porembski and W. Barthlott (Editors), Inselbergs. Biotic Diversity of Isolated Rock Outcrops in Tropical and Temperate Regions Springer, Berlin, pp. 7-35.

Brêthes, A., Brun, J. J., Jabiol, B., Ponge, J. F. and Toutain, F., 1995. Classification of forest humus forms: a French proposal. Ann. Sci. For., 52: 535-546.

Didden, W. A. M., 1990. Involvement of Enchytraeidae (Oligochaeta) in soil structure evolution in agricultural fields. Biol. Fertil. Soils, 9: 152-158.

Garay, I. and Hafidi, N., 1990. Study of a mixed forest litter of hornbeam (Carpinus betulus L.) and oak (Quercus sessiliflora Smith). III. Organization of the edaphic macroarthropod community as a function of litter quality. Acta Oecol., 11: 43-60.

Green, R. N., Trowbridge, R. L. and Klinka, K., 1993. Towards a taxonomic classification of humus forms. For. Sci. Monogr., 29: 1-49.

Greenacre, M. J., 1984. Theory and Applications of Correspondence Analysis. Academic Press, London. 
1 Grimaldi, M. and Riéra, B., 2001. Geography and climate. In: F. Bongers, P. CharlesDominique, P. M. Forget and M. Théry (Editors), Nouragues: Dynamics and PlantAnimal Interactions in a Neotropical Rainforest. Kluwer, Dordrecht, pp. 9-18.

Hambler, D.J., 1964. The vegetation of granitic outcrops in western Nigeria. J. Ecol., 52: 573594.

Kounda-Kiki, C., Vaçulik, A., Ponge, J. F. and Sarthou, C., 2004. Soil arthropods in a developmental succession on the Nouragues inselberg (French Guiana). Biol. Fertil. Soils, 40: 119-127.

Lavelle, P., 1984. The soil system in the humid tropics. Biology International, 9: 2-17.

Lavelle, P., Blanchart, E., Martin, A., Spain, A., Toutain, F., Barois, I. and Schaefer, R., 1993. A hierarchical model for decomposition in terrestrial ecosystems: applications to soils of the humid tropics. Biotropica, 25: 130-150.

Lips, J.M. and Duivenvoorden, J.F., 1996. Fine litter input to terrestrial humus forms in Colombian Amazonia. Oecologia, 108: 138-150.

Loranger, G., Ponge, J.F. and Lavelle, P., 2003. Humus forms in two secondary semievergeen tropical forests. Eur. J. Soil Sci., 54: 17-24.

Peltier, A., Ponge, J. F., Jordana, R. and Ariño, A., 2001. Humus forms in Mediterranean scrublands with aleppo pine. Soil Sci. Soc. Am. J., 65: 884-896. 
2 Ponge, J. F., 1991. Food resources and diets of soil animals in a small area of Scots pine litter. Geoderma, 49: 33-62.

4

Sadaka, N. and Ponge, J. F., 2003. Climatic effects on soil trophic networks and the resulting humus profiles in holm oak (Quercus rotundifolia) forests in the high Atlas of Morocco as revealed by correspondence analysis. Eur. J. Soil Sci., 54: 767-777.

Sarthou, C., 1992. Dynamique de la Végétation Pionnière sur un Inselberg en Guyane Française. Doctorate thesis, Paris.

Sarthou, C., 2001. Plant communities on a granitic outcrop. In: F. Bongers, P. CharlesDominique, P.M. Forget and M. Théry (Editors), Nouragues: Dynamics and PlantAnimal Interactions in a Neotropical Rainforest. Kluwer, Dordrecht, pp. 65-78.

Sarthou, C. and Grimaldi, C., 1992. Mécanismes de colonisation par la végétation d'un inselberg granitique en Guyane Française. Rev. Ecol. Terre Vie, 47: 329-349.

Sarthou, C., Thérèzien, Y. and Couté, A., 1995. Cyanophycées de l'inselberg des Nouragues (Guyane française). Nova Hedwigia, 61: 85-109.

Sarthou, C. and Villiers, J. F., 1998. Epilithic plant communities on inselbergs in French Guiana. J. Veg. Sci., 9: 847-860. 
1 Sarthou C., Villiers, J. F. and Ponge J. F., 2003. Shrub vegetation on tropical granitic inselbergs (French Guiana). J. Veg. Sci., 14: 645-652.

3

4 Topoliantz, S., Ponge J. F. and Viaux, P., 2000. Earthworm and enchytraeid activity under 5 different arable farming systems, as exemplified by biogenic structures. Plant Soil, 6 225: 39-51.

7

8 Vaçulik, A., Kounda-Kiki, C., Sarthou, C. and Ponge, J. F., 2004. Soil invertebrate activity in 9 biological crusts on tropical inselbergs. Eur. J. Soil Sci., 55: 539-549.

10 


\section{$1 \quad$ Figure captions}

2

3 Fig. 1. Distribution according to depth of cyanobacteria (a), leaf material (b), root material (c), decayed plant material (d), fungal mycelia (e), humified organic matter (f), holorganic faeces (g), organo-mineral faeces (h) and mineral particles (i) under the three main vegetation types.

7

Fig. 2. Correspondence analysis of humus layers. Projection of active variables (categories of litter/humus components) in the plane of the first two axes. Categories were coded as in Table 1.

Fig. 3. Correspondence analysis of humus layers. Projection of passive variables (horizon names, depth indicators and vegetation types) in the plane of the first two axes. Depth levels (from $\mathrm{cm}$ to $\mathrm{cm}$ ) are indicated by broken lines for each of the three sampled successional stages, starting from 0-1 cm. Dotted line = Pitcairnia stage, hyphened line $=$ Clusia stage, full line $=$ Clusia-Myrcia stage. 
Table 1. Mean volumes (in $\% \pm \mathrm{SE}$ ) of gross categories featuring litter/humus components in the three studied successional stages Pitcairnia, Clusia and Clusia-Myrcia (three replicates each).

\begin{tabular}{lcccc}
\hline \multicolumn{1}{c}{ Gross category } & Code & Pitcairnia & Clusia & Clusia-Myrcia \\
\hline Leaf material & LM & $6.4 \pm 4.3$ & $22 \pm 7.1$ & $17 \pm 6.7$ \\
Root material & RM & $23 \pm 2.1$ & $49 \pm 7.2$ & $39 \pm 3.7$ \\
Decayed plant material & DPM & $11 \pm 7.1$ & $2.6 \pm 0.9$ & $5.0 \pm 1.9$ \\
Miscellaneous plant & MP & $1.7 \pm 1.3$ & $1.1 \pm 0.2$ & $1.2 \pm 0.2$ \\
Cyanobacteria & C & $46 \pm 20$ & 0 & 0 \\
Fungal mycelium & F & $0.8 \pm 0.1$ & $6.1 \pm 3.5$ & $3.1 \pm 1.5$ \\
Humified organic matter & HOM & $36 \pm 7.6$ & $20 \pm 5.0$ & $32 \pm 6.7$ \\
Holorganic faeces & HF & $10.4 \pm 6.4$ & $16 \pm 0.5$ & $13 \pm 2.3$ \\
Organo-mineral faeces & OMF & 0 & $1.3 \pm 1.1$ & $0.01 \pm 0.01$ \\
Mineral particles & MP & $4.4 \pm 0.9$ & $1.5 \pm 0.9$ & $0.36 \pm 0.22$ \\
\hline
\end{tabular}



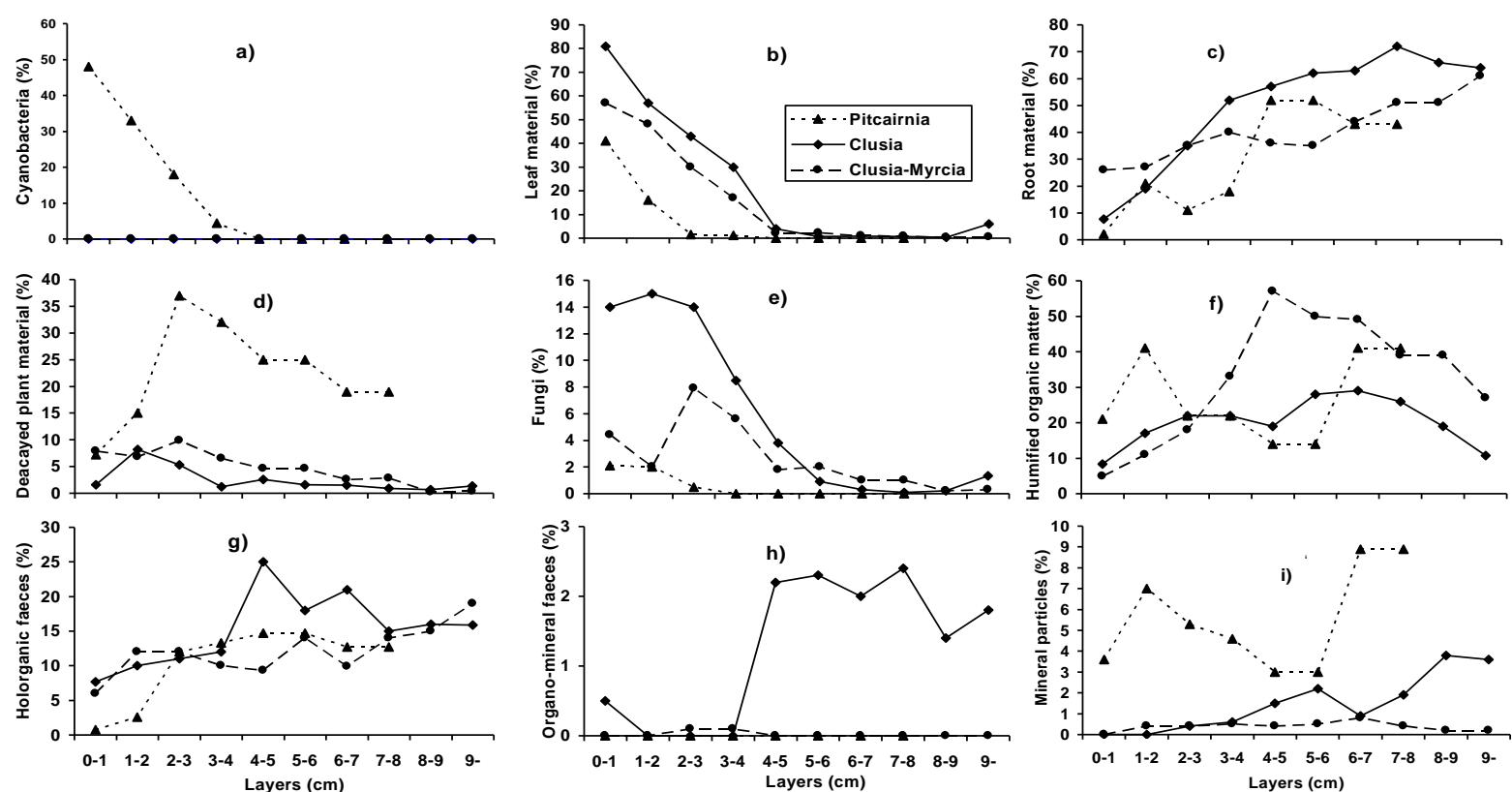

Fig. 1 


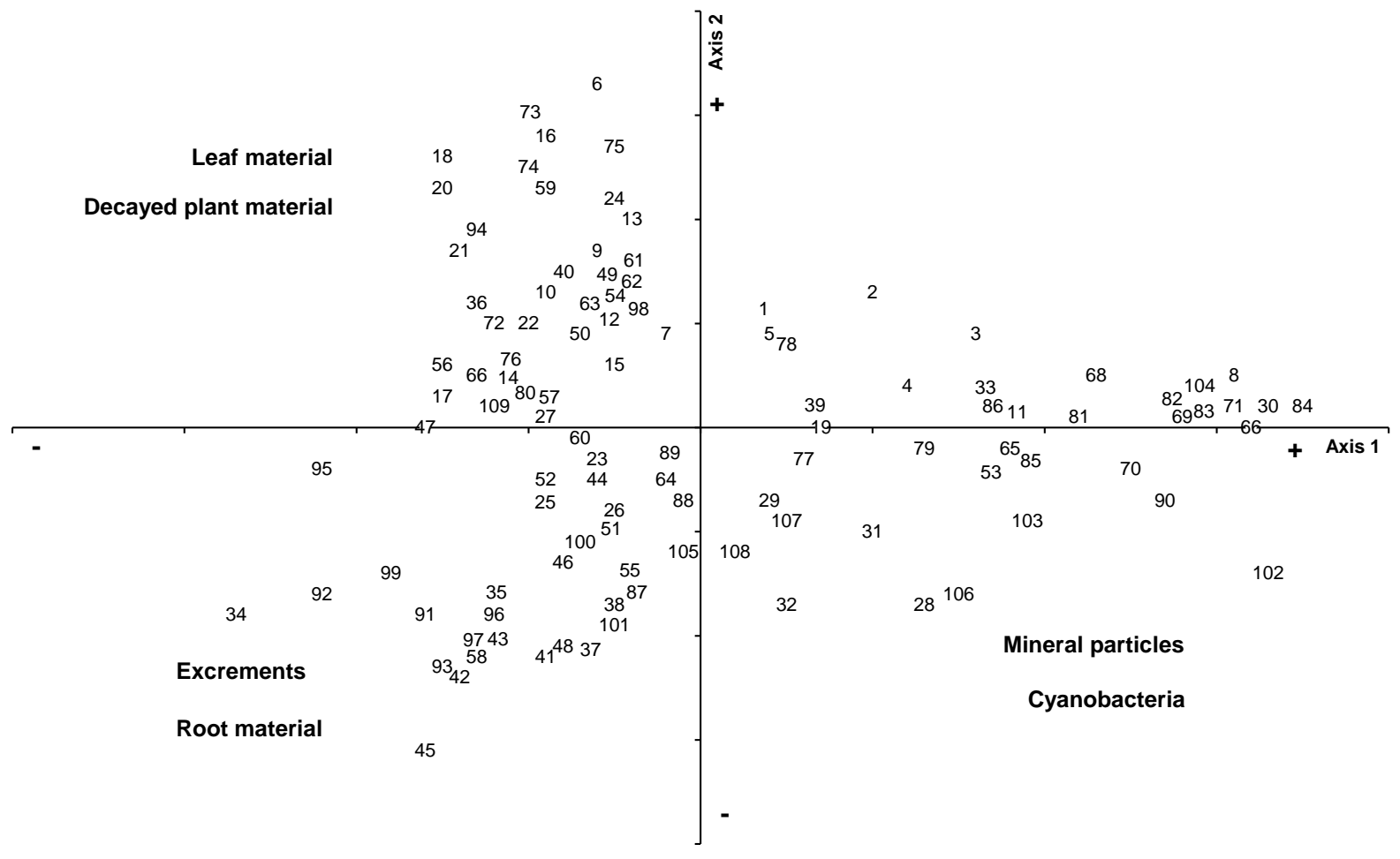

2 Fig. 2

3 


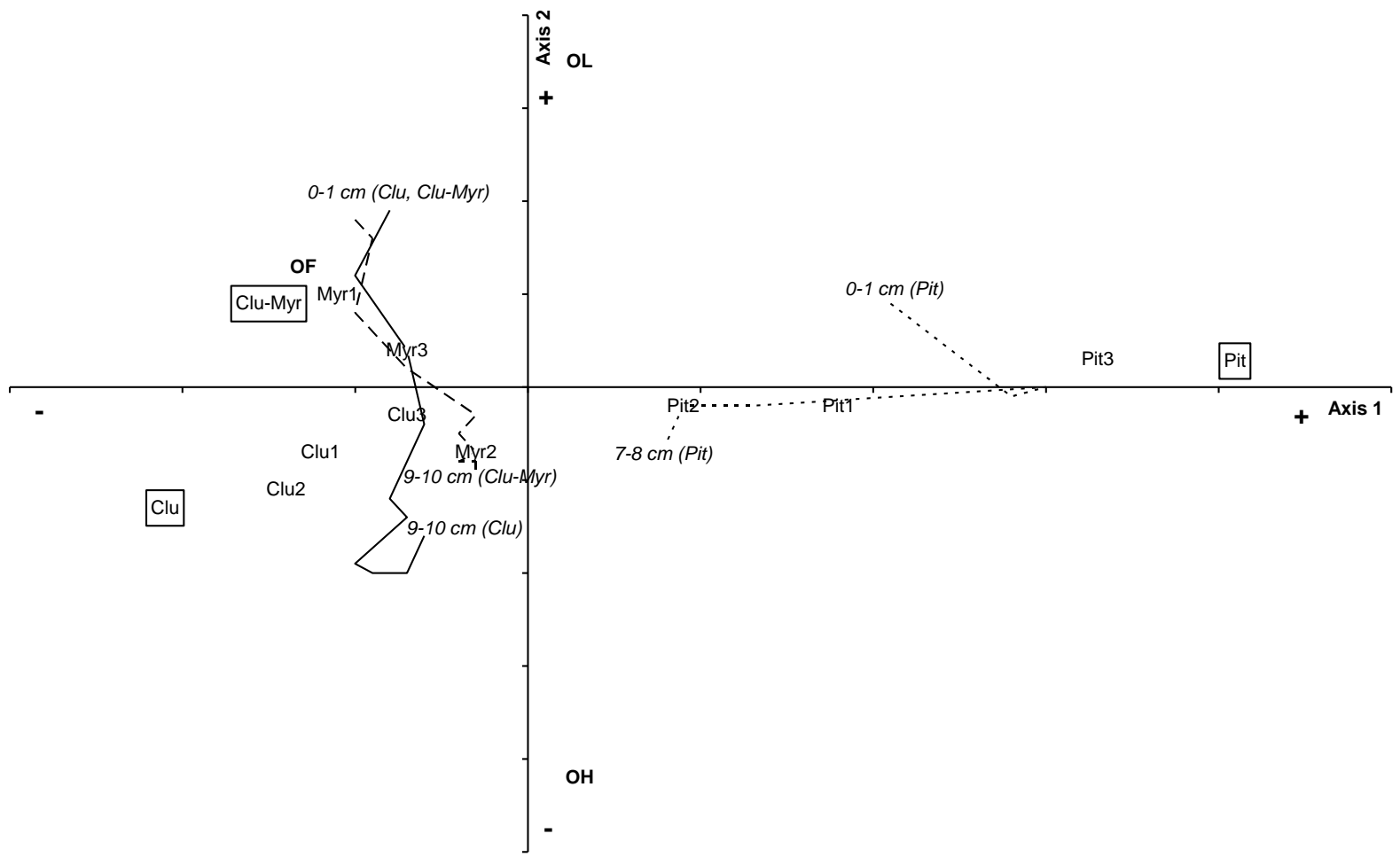

$2 \quad$ Fig. 3

3 
Appendix. Classes of litter/humus components and enchytraeids counted under the dissecting microscope with their code number and volume (in \%) according to a count-point method in the nine profiles studied. Pitcairnia, Clusia and Clusia-Myrcia are three stages of a plant succession on the Nouragues inselberg. $\mathrm{C}=$ cyanobacteria. $\mathrm{DPM}=$ decayed plant material. $\mathrm{F}=$
fungal mycelium. $\mathrm{LM}=$ leaf material. $\mathrm{HF}=$ holorganic faeces. $\mathrm{HOM}=$ humified organic matter. $\mathrm{MP}=$ mineral particles. $\mathrm{MPM}=$ miscellaneous plant material. $\mathrm{OMF}=$ organo-mineral feaces. $\mathrm{RM}=$ root material.

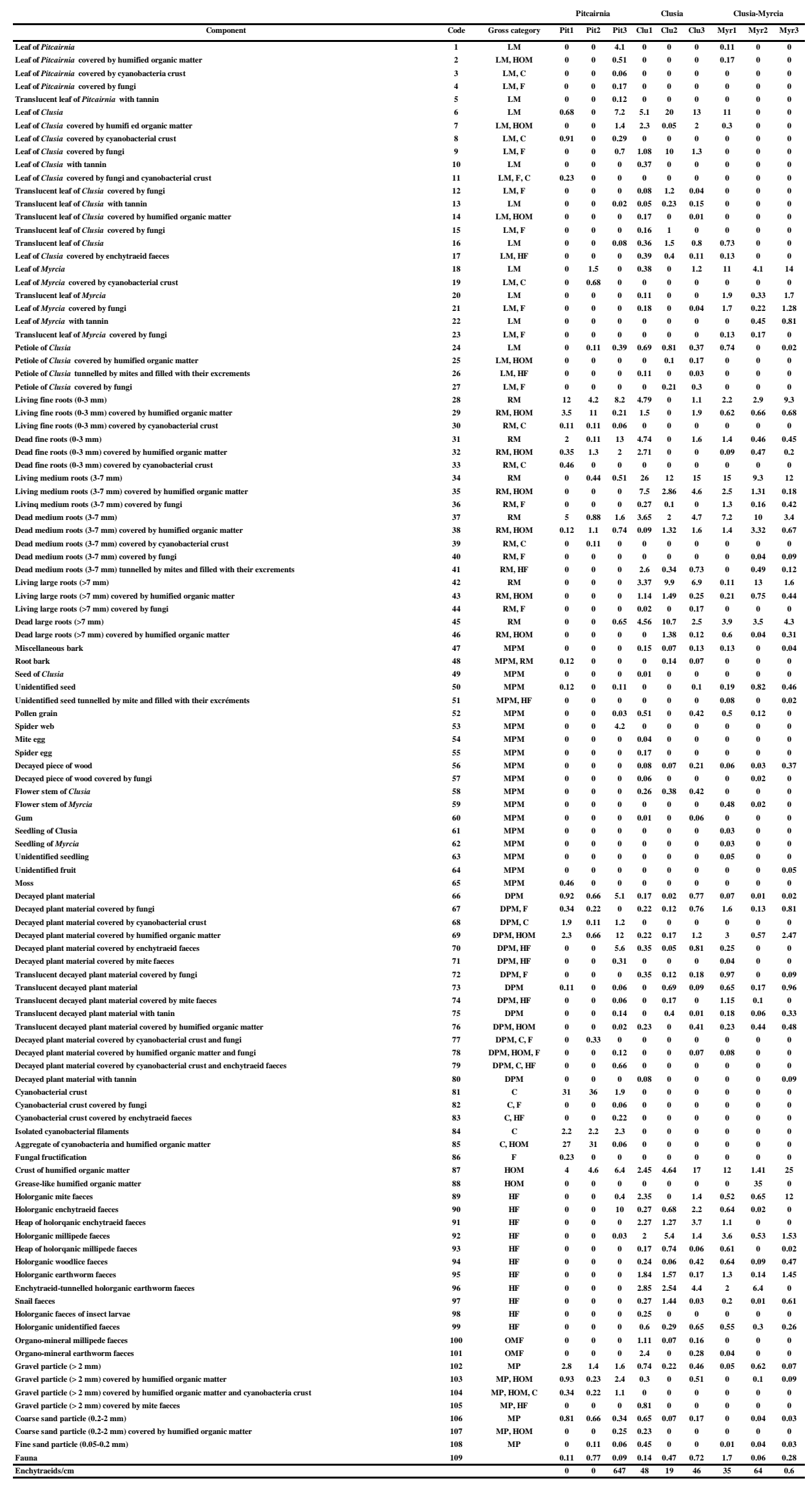

